\title{
Proposition for the application of a grid-connected photovoltaic (PV) system: Koya city as a study case
}

\author{
A. A. Abdulrahman \\ Koya University, Iraq
}

\begin{abstract}
Renewable energy is energy that is derived from natural processes that are replenished constantly. Unlike fossil fuel, renewable energy does not pollute the environment because it is a part of nature. Renewable sources that are most often used are solar, wind, water (hydropower), biomass and geothermal energy. The potential to generate energy from renewable sources is largely dependent on the availability of these natural resources. Among the renewable energy resources, the energy through the photovoltaic (PV) - which converts the sunlight directly into electricity - can be considered the most essential and prerequisite sustainable resource. The standalone PV system cannot provide a continuous supply of energy due to seasonal and periodic variations. Therefore, in order to satisfy the load demand, grid-connected energy systems are now being implemented that combine the PV system with the grid system. The gridconnected PV system can be divided into two parts: building integrated PV systems (BIPV) and distribution generation PV (DGPV) systems. BIPV systems usually supply a specific load and inject the excess energy to the grid while DGPV systems directly inject the energy to the grid. The suggestion in this paper is that the BIPV system is applied for some special building in a Koya city like: the university's new presidency building, Shaid-Khalid new hospital and the new bank buildings. This application will be the first step of going toward renewable energy usage with the grid system in Kurdistan region.
\end{abstract}

Keywords: grid-connected system, photovoltaic, renewable energy. 


\section{Introduction}

Energy plays a pivotal role in our daily activities. The degree of development and civilization of a country is measured by the amount of utilization of energy by human beings. Energy demand is increasing day by day due to increase in population, urbanization and industrialization. The world's fossil fuel supply viz. coal, petroleum and natural gas will thus be depleted in a few hundred years. The rate of energy consumption increasing, supply is depleting resulting inflation and energy shortage. This is called energy crisis. Hence alternative or renewable sources of energy have to be developed to meet future energy requirement [1]. One of the renewable sources developed now, is the solar energy which is used in the photovoltaic system (PV). It is the system which converts sunlight into electrical energy and it can literally be translated as light-electricity. Based on the fact that PV systems are clean, environment friendly, and secure energy sources, PV system installation has played an important role worldwide. Recently, photovoltaic system is likely recognized and widely utilized to the forefront in electric power applications. From this point of view, the power provided by PV system connected with the grid system. So the grid-connected PV systems (BIPV and DGPV) were developed.

PV grid-connected systems are installed worldwide because they allow consumers to reduce energy consumption from the electricity grid and to feed the additional energy back into the grid.

The objective of this study is to suggest for using the PV grid-connected system for the three buildings inside Koya city which are University Presidency, new Bank and Shahid-Khalid hospital buildings. The purpose of using this system is providing the electricity for the buildings during the day and injects the exceeded electricity to the grid system. This process is important from these points of view:

1- Reduce the bill in electricity.

2- Return building electricity and exceeded power generated from the PV system to the grid system.

3- Injecting the generated power to the grid system during the day of the holidays.

4- It will be the first step of using a grid-connected PV system in Kurdistan region which can be counted as an important step toward urbanization development and renewable energy source usage in the region.

The rest of this paper is organized as follows: in Section 2, the world gridconnected PV system overview is described. Section 3 explains a simple idea about the photovoltaic system while the grid-connected PV system and its components are introduced in Section 4. In Section 5, grid-connected PV system calculations are cleared and a proposition for application grid-connected PV system to Koya city is discussed in Section 6. Finally the conclusion is represented in Section 7. 


\section{World grid-connected PV system overview}

The first large sized (1MW) grid interactive PV power plant was installed in Lugo in California, USA. The second and largest (6.5MW) plant was installed in Carissa Plains, California, USA. Also some other large sized plant are operating in various countries and many other proposed in Italy, Switzerland, Germany, Australia, Spain and Japan. Several small capacity systems in the range of $25 \mathrm{KW}-200 \mathrm{KW}$ are being experimentally tried out in Africa, Asia and Latin America. In India, $33 \mathrm{PV}$, grid-connected plants with the total installed capacity of 2.54 MW have been installed so far, and another $550 \mathrm{KW}$ aggregate installed capacity plants are undergoing installation process. A $200 \mathrm{KW}$ grid interactive PV plant installed recently at village Khatkarkalan, Dt- Nawanshahr of Punjab. Also a large number of small rooftop grid-interactive systems are successfully being operated in various parts of the world [1].

\section{Photovoltaic (PV) system}

Photovoltaic (or PV) systems convert light directly into electricity. The term photo comes from the Greek phos, which means "light." The term volt is a measure of electricity named for Alessandro Volta (1745-1827), a pioneer in the development of electricity. Photovoltaic literally means light-electricity [2].

A photovoltaic (PV), or solar electric system, is made up of several photovoltaic solar cells. An individual PV cell is usually small, typically producing about 1 or 2 watts of power. To boost the power output of PV cells, they are connected together to form larger units called modules [3]. Modules, in turn, can be connected to form even larger units called arrays (as shown in figure 1), which can be interconnected to produce more power, and so on. In this way, PV systems can be built to meet almost any electric power need; small or large [3].

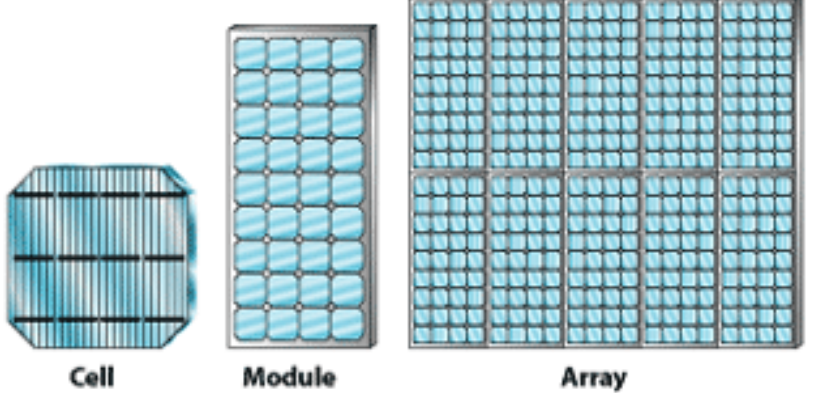

Figure 1: $\quad$ Cell, module and array of PV system.

\section{Grid-connected PV system}

Grid-connected PV systems employ the direct conversion of sunlight into electricity which is fed directly into the electricity grid without storage in 
batteries. This will be a very good way to boost the existing electricity production capacity in the country [2]. The system can be an effective way to reduce the dependence on the utility power, increase renewable energy production, and improve the environment [4].

The grid-connected PV system consists of the following main parts (as shown in Figure 2) [3]:

- $\quad$ Solar PV modules: PV modules generate direct current (DC) electricity when exposed to sunlight.

- Inverter: an inverter converts the DC to alternating current (AC) electricity and synchronises it to the grid so it can feed seamlessly into the building's AC distribution board (ACDB).

- $\quad$ Meter: it is used to record the flow of electricity to and from the grid.

- Substation: the power grid itself to connect too, because without the utility grid it is not a grid-connected PV system.

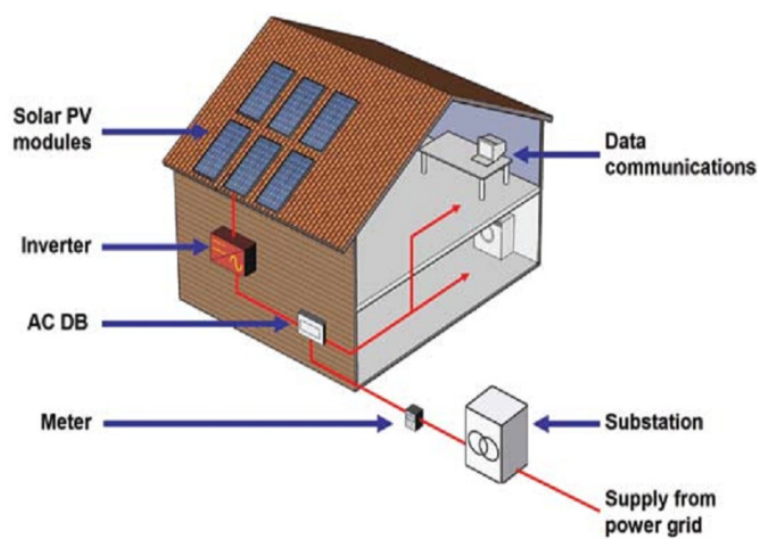

Figure 2: $\quad$ Grid-connected solar PV system configuration.

At night, power grid supplies $100 \%$ of the demand. During the day, the PV system supplies anything from 0 to $100 \%$, depending on its size relative to demand, and the intensity of the sunshine. In case the PV system generates more than the building's demand, excess electricity will feed back into the power grid [5].

If for any reason the grid should fail, or stray beyond voltage or frequency tolerances, the PV inverters will automatically disconnect. This is a safety feature but it means a grid-connected PV system generally cannot operate when the grid is down [5].

\section{Grid-connected PV system calculation}

In general, the most common optimization methodology that is followed by the researchers starts by defining a specific area, and then a time series data for solar energy, ambient temperature must be obtained. After that, the calculation of 
optimum tilt angle is conducted by modelling the solar energy on a tilt surface and then the calculation of system energy source optimum capacity is done.

Finally, the size of the inverter in the PV system is calculated optimally [6]. Table1 shows the most important parameters which are necessary for the system design calculations $[4,6,7]$ :

Table 1: $\quad$ Most important parameter of the grid-connected PV system.

\begin{tabular}{|c|l|c|l|}
\hline No & Parameter name & No & Parameter name \\
\hline 1 & PV array module specification & 6 & Annual yield factors \\
\hline 2 & Inverter specification & 7 & Annual capacity factor \\
\hline 3 & Ambient temperature & 8 & Life cycle cost \\
\hline 4 & Solar radiation & 9 & Performance ratio \\
\hline 5 & Energy generation cost & 10 & Payback period \\
\hline
\end{tabular}

The module and inverter cost alone makes up about $76 \%$ of the total investment cost [6]. As pointed in [8,9] and, according to NREL Energy Analysis office, it is expected that the unit cost of PV energy will be half of the present day value until 2025 that decline is quite high compared to other renewable systems as shown in figure 1 below:

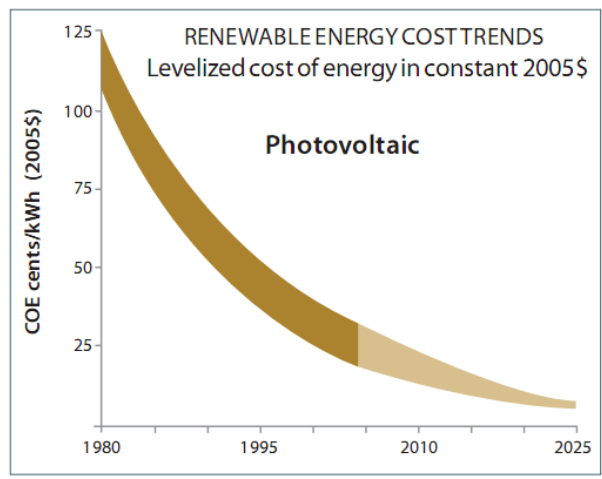

Figure 1: $\quad$ Unit cost of PV system declination [4].

\section{Proposition for application of a grid-connected PV system to Koya city}

This paper suggests applying the grid-connected PV system for Koya city. It will be the first step in employing one of the renewable energy sources which is solar in the city and it will be the first attempt in Kurdistan region to parallel operation of PV system and grid instantaneously. For this purpose we will point out three buildings to install the BIPV system. They are the new presidency, the new bank and the Shahid-Kahlid hospital buildings because they have appropriate positions 
in these points of view like: specific area; prevent shadowing; empty building squint; suitable north face of them for installation.

The process of new system installation passes in two stages: the first is the decision of the building responsible directory. They will decide to choose the capacity of the system as they want. Do they want to provide $100 \%$ of the electricity to the building due to the new system during the day or any other percent from $0-100 \%$ by new system with the help of grid system?

After the decision of the capacity, the primary calculation for the system depend on that capacity will be done. The cost and most important parameter of the system will indicate and it will make a report so as to be studied by the person. If the system is accepted, then the second stage will start.

The second stage is the accurate calculation for the system which consists of the following procedure:

1- Obtaining the solar radiation data for the location which helps to estimate the amount of electricity can be generated.

2- Obtaining a land use map of the location showing the various sites that can be used for the project and confirm the various locations on the land use map and update where necessary. Also, identify various building roofs that can be used for the project based on a minimum roof area.

3- Obtaining the dimensions of the roofs of the selected buildings to be used and assessment of roof properties such as type, area, orientation, pitch/slope, strength and the effect of shading on it. Also, selection of suitable roofs and collation the total area available PV system design.

4- Obtaining solar PV information from various solar dealers both locally and internationally. This information should include; type, cost, size, weight, etc.

5- Identifying grid access and requirement for grid connection.

6- Designing the layout of the system for each of the selected building roofs.

The first stage explanation will be done in the following bench mark system design. Suppose a system of $2.7 \mathrm{KW}$ for each of the buildings is decided.

\subsection{Design of 2.7 KW grid-connected PV system}

To design this system, we will choose a PV module and inverter which their specification shown in tables 2 and 3 respectively. After calculation, the system and economic results are shown in tables 4 and 5 respectively.

Table 2: $\quad$ PV module specification [7, 8].

\begin{tabular}{|l|l|}
\hline Watt & 150 watt \\
\hline Voltage & 25 volt \\
\hline Current & $5.5 \mathrm{~A}$ \\
\hline Type & Polycrystalline \\
\hline Efficiency & $14.3 \%$ \\
\hline Area & $1.25 \mathrm{~m}^{2}$ \\
\hline
\end{tabular}


Table 3: $\quad$ Inverter specification [7, 8].

\begin{tabular}{|l|l|}
\hline Output & 240 Volt \\
\hline $\begin{array}{l}\text { Max. Ac power } \\
\text { output }\end{array}$ & $2800 \mathrm{~W}$ \\
\hline Input current & $12.4 \mathrm{~A}$ \\
\hline Efficiency & $95 \%$ \\
\hline Nominal frequency & $50 \mathrm{~Hz} / 60 \mathrm{~Hz}$ \\
\hline
\end{tabular}

Table 4: $\quad$ System result calculation.

\begin{tabular}{|l|l|}
\hline No. of PV module requirement & 18 \\
\hline No. of module in parallel & 2 \\
\hline No. of module in series & 9 \\
\hline Required area (m²) & 22.5 \\
\hline Output voltage (volt) & 225 \\
\hline Output current (A) & 11 \\
\hline Required system rating/year (KWh/year) & 10 \\
\hline
\end{tabular}

Table 5: $\quad$ Economic result calculation.

\begin{tabular}{|l|l|}
\hline Capital cost of the system & $\$ 13500$ \\
\hline Nominal life time & 25 \\
\hline Cost/KWh (\$/KWh) & 0.18 \\
\hline Payback period (year) & 45 \\
\hline
\end{tabular}

\section{Conclusions}

With an estimated world average growth rate of $2.8 \%$, the electricity demand is expected to be doubled in 2020. During this period, the electricity demand in developing countries is projected to increase by $4.6 \%$ annually. To provide this expansion it will be planned to generate some of this amount from the renewable energy source especially the solar source by using the grid-connected PV system. It will be expected the $20 \%$ of electricity come from the renewable energy in 2030 particularly while the cost of PV system come down day by day.

In this study we proposed to use the grid-connected PV system in Koya city for the purpose of introducing Koya city as the first city in Kurdistan region for using this modern system also for the contribution it in the urban development from this countenance. On the other hand, installation this new system provides 
the light electricity(i.e. electricity without pollution) to the end users which is economic for them, however the cost may be not enough cheaper than the governmental electricity but this issue will gradually be solved in the next few years.

In this paper a $2.7 \mathrm{KW}$ system was designed as a bench mark design. Due to the flexibility of PV module, any electricity demand can be designed by using this new system. In the future, the establishment of utilization technology for stability and reliability of PV systems will take on more significance in this area as high-density grid-connected PV systems will be interconnected with distribution networks.

\section{References}

[1] Jasvir S., Study and Design of Grid Connected Solar Photovoltaic system at Patiala, Punjab. Thesis, Thapar University, Patiala, 2010.

[2] Ebenezer N. K., Abeeku B., Design and Analysis of a 1MW Grid-Connected Solar PV System in Ghana. African Technology Policy Studies Network, 2013.

[3] David Tan, Ang Kian Seng, Handbook for Solar Photovoltaic (PV) Systems. Energy Market Authority, Building and Construction Authority, 2011.

[4] Herbert Giardet, Miguel Mendonca, A Renewable World Energy, Ecology, Equality. Green Books Ltd, UK, 2009.

[5] The Centre for Sustainable Buildings and Construction, building planning and massing. Building and Construction Authority, 2010.

[6] Ali Hajiah, Tamer Khatib, K. Sopian, M. Sebzali, Performance of GridConnected Photovoltaic System in Two Sites in Kuwait. International Journal of Photo Energy, 7 pages, 2012.

[7] Subarto K. G., Mohammad H. S., Ashifur R., Mahzuba I., Case Study of Grid Connected PV System at Northern Part of Bangladesh. International Journal of Scientific \& Engineering Research, Volume 4, Issue 5, May 2013.

[8] Irfan G., Nevzat O., Paths to Sustainable Energy. Book, Intec, 2010.

[9] A.S. Elhodeiby, H.M.B. Metwally, M.A. Farahat, Performance Analysis of 3.6 KW Rooftop Grid Connected Photovoltaic System in Egypt. International Conference on Energy Systems and Technologies, Cairo, Egypt, March 2011. 